\title{
PEMANFAATAN AIR OLAHAN WETLAND DI SITIMULYO DALAM PEMBUATAN PIKEL KULIT DOMBA
}

\section{(THE UTILIZATION OF TREATED WETLAND WATER IN SITIMULYO ON THE MAKING OF PICKLED SHEEPSKIN)}

\author{
Dwi Ningsih, Teguh Martianto, Syaiful Harjanto \\ Balai Besar Kulit, Karet dan Plastik, Yogyakarta \\ Email: duinatha@gmail.com
}

Diterima: 8 September 2012 Direvisi: 22 Oktober 2012 Disetujui: 11 Nopember 2012

\begin{abstract}
Research has been done to study the effects of treated wetland water utilization in Sitimulyo on the making of pickled sheepskin. The treated wetland water on the making of pickled sheepskin was done by using three variable ratio of wetland water: water that is 100:0; 75:25; 50:50. Used as a comparison was control or without any additional water wetland. Skin that was used as much as 12 pieces of sheepskin divided into 4 groups and 3 pieces of leather for each treatment. Quality parameters observed include skin moisture content, salinity, $\mathrm{pH}$, and organoleptic observation. From the results showed that the treated wetland water in Sitimulyo not meet the water requirements for tanning leather according to SNI 06-0649-1989 on water for vegetable leather tanning process. Pickle skin test results show that the chemical (moisture, salt and $\mathrm{pH}$ ) and organoleptic not meet the requirements of SNI 06-3537-1994 on quality leather and test methods pickle sheep.
\end{abstract}

Keywords: pickle leather, wetland water, sheepskin

\begin{abstract}
ABSTRAK
Telah dilakukan penelitian untuk mempelajari pengaruh penggunaan air olahan wetland yang ada di Sitimulyo dalam pembuatan kulit pikel domba. Air olahan wetland dalam pembuatan kulit Pikel dilakukan dengan 3 variabel perbandingan air wetland:air bersih yaitu 100:0; 75:25; 50:50. Sebagai pembanding digunakan kontrol atau tanpa tambahan air wetland. Kulit yang digunakan sebanyak 12 lembar kulit domba dibagi dalam 4 kelompok dan 3 lembar kulit untuk masing-masing perlakuan. Parameter mutu kulit yang diamati meliputi kadar air, kadar garam, $\mathrm{pH}$, serta pengamatan organoleptis. Dari hasil penelitian menunjukkan bahwa air olahan wetland yang ada di Sitimulyo belum memenuhi persyaratan air untuk penyamakan kulit sesuai SNI 060649-1989 mengenai air untuk proses penyamakan kulit samak nabati. Hasil uji kulit pikel menunjukkan bahwa secara kimia (kadar air, garam dan $\mathrm{pH}$ ) dan organoleptis tidak memenuhi persyaratan SNI 06-3537-1994 mengenai mutu dan cara uji kulit pikel domba.
\end{abstract}

Kata kunci: kulit pikel, air wetland, kulit domba

\section{PENDAHULUAN}

Proses penyamakan kulit adalah proses merubah kulit mentah (hide atau skin) yang bersifat labil menjadi kulit tersamak yang bersifat stabil. Proses tersebut dimaksudkan untuk mengubah sifat-sifat kulit mentah yang mudah mengalami kerusakan dan pembusukan menjadi kulit tersamak yang tahan terhadap aktifitas mikroorganisme dan pembusukan. (Purnomo, 2005). Dalam proses merubah kulit mentah menjadi kulit tersamak dilakukan dalam 3 tahapan utama yaitu proses pra penyamakan (beam house), proses penyamakan dan proses pasca penyamakan. Proses beam house adalah proses pengubahan kulit mentah sampai menjadi kulit Pikel. 
Menurut SNI. 06-3537-1994 kulit pikel adalah kulit mentah yang telah mengalami proses pengapuran dan diawet dengan cara pengasaman/pickling.

Pada proses penyamakan kulit, harus diingat bahwa kulit merupakan bahan organik yang mempunyai sifat-sifat yang masih sangat sensitif terhadap beberapa jenis kemikalia serta mikroorganisme. Oleh karena itu segala sesuatunya harus dipersiapkan dan diperhitungkan secermat mungkin agar kulit mentah tidak mengalami kerusakan baik oleh perlakuan-perlakuan kimia, fisik maupun mikroorganisme selama berlangsungnya proses penyamakan. Salah satu faktor yang penting dalam penyamakan kulit adalah kondisi kemikalia yang digunakan termasuk air. Air merupakan perantara/ medium untuk menyampaikan bahan-bahan lain ke dalam kulit. Air untuk penyamakan tidak boleh mengandung zat-zat yang dapat bereaksi dengan bahan yang digunakan dalam proses penyamakan kulit karena akan mempengaruhi proses penyamakan tersebut. Air yang digunakan untuk penyamakan harus jernih, tidak mengandung mikroorganisme dan bebas dari garam-garam besi dan kesadahan. (Jayusman, 1990).

Air merupakan salah satu faktor penting yang harus diperhatikan dalam proses penyamakan kulit. Jumlah air yang dibutuhkan dalam proses tergantung pada jenis kulit yang akan dihasilkan. Kebutuhan jumlah air menurut Rajamani (1999) untuk 1 ton kulit mentah awet garaman dalam tiap tahapan proses dapat dilihat pada tabel 1 .

Tabel 1. Karakteristik Limbah Cair Industri Penyamakan

\begin{tabular}{lcccccc}
\hline \multicolumn{1}{c}{ Parameter } & Soaking & Liming & Deliming & Pickling & $\begin{array}{c}\text { Chrome } \\
\text { Tanning }\end{array}$ & $\begin{array}{c}\text { Campuran } \\
\text { termasuk } \\
\text { pencucian }\end{array}$ \\
\hline $\begin{array}{l}\text { Volume limbah } \\
\text { cair per ton } \\
\text { hide/skin, } \mathrm{m}^{3}\end{array}$ & $6-9$ & $3-5$ & $1-2$ & $0,5-1$ & $1-2$ & $30-40$ \\
$\mathrm{pH}$ & $7,5-8$ & $3-5$ & $1-2$ & $0,5-1$ & $1-2$ & $7-9$ \\
\hline
\end{tabular}

Syarat kualitas air dalam setiap tahapan proses adalah sebagai berikut:

1. Perendaman (soaking)

Kesadahan sedang sedikit membahayakan. Kandungan bahan tersuspensi yang tinggi atau adanya pembusukan bakteri itu yang tidak diharapkan

2. Pengapuran (liming)

Air sadah tidak berbahaya bagi kulit putih kapur dan cairan kapur sulfida, tetapi tidak boleh digunakan dalam proses pengapuran dengan larutan enzim kapur.

3. Pencucian setelah liming, deliming dan bating

Kandungan yang tinggi dari karbonat kemungkinan menyebabkan lime blast dan efek enzimatik terganggu pada proses bating.

4. Pickling dan Penyamakan krom

Air sadah tidak berbahaya
Klasifikasi air berdasarkan kesadahan total adalah sebagai berikut:

$0-4^{\circ} \mathrm{G} \quad$ : air sangat lunak

4- $8^{\circ} \mathrm{G} \quad$ : air lunak

$8-12^{\circ} \mathrm{G} \quad$ : air lunak sedang

$12-18^{\circ} \mathrm{G}$ : air cukup sadah

$18-30^{\circ} \mathrm{G} \quad$ : air sadah

$>30^{\circ} \mathrm{G} \quad$ : air sangat sadah

1 Derajat Jerman $\left({ }^{\circ} \mathrm{G}\right)=1$ bagian $\mathrm{CaO}$ dalam 100.000 bagian air $=10 \mathrm{mg} / \mathrm{L}=0,357$ mval/Lion alkali tanah.

Dalam proses penyamakan kulit dibutuhkan air yang relatif besar. Menurut Rajamani (1999) untuk 1 ton kulit mentah awet garaman membutuhkan $30-40 \mathrm{~m}^{3}$ air. Hal ini menyebabkan limbah cair yang dihasilkan melimpah. 
Limbah cair yang dihasilkan diolah dengan tiga tahapan utama yaitu pengolahan primer, sekunder, dan tersier. Pengolahan primer meliputi pengolahan fisik dan pengolahan kimia. Pengolahan sekunder meliputi pengolahan biologi. Sedangkan pengolahan tersier salah satunya dapat berupa proses penjernihan dengan sistem wetland. Air outlet dari hasil pengolahan biologi selanjutnya diolah menggunakan wetland. Wetland adalah sistem pengolahan air limbah dengan memanfaatkan tanaman air, berlangsung melalui proses fisika, kimia dan biologi yang disebabkan oleh adanya interaksi antara mikrobiologi, tanaman dan substrat. (Anonim, 2007). Proses pengolahan limbah penyamakan terbaik dapat dihasilkan dengan kombinasi proses pengolahan fisika/kimia dengan proses biologi. Kombinasi proses pengolahan limbah akan memberikan hasil yang memuaskan bila dibandingkan dengan pengolahan sendiri-sendiri. Pengolahan secara biologi nampaknya merupakan metode pilihan terbaik untuk menghilangkan warna dan kandungan bahan organik. (G. Durai, 2011).

Prinsip dasar sistem wetland untuk pengolahan air limbah adalah pada proses respirasi tumbuhan air. Menurut Prayitno dkk., (2011), wetland cukup efektif untuk mengurangi BOD, COD, TSS, N-NH3, kadar sulfida, lemak dan krom.

Proses-proses yang terjadi dalam sistem pengolahan air limbah dengan memanfaatkan tanaman air adalah :

a. Proses fisika dengan mekanisme removal sedimentasi dan filtrasi.

b. Proses fisika dan kimia dengan mekanisme removal adsorpsi dan presipitasi fosfor dan logam berat.

c. Proses biokimiawi dengan mekasnisme removal penurunan bahan organik, nitrifikasi, denitrifikasi, dekomposisi anaerobik, penyerapan tumbuhan air. (Iwan. K, 2011).

Dalam keadaan umum, kerusakan/cacat dapat terjadi ketika air limbah digunakan secara langsung dalam recycle. Sebagai contoh air limbah soaking dan deliming dapat menyebabkan permukaan kasar, air limbah krom dapat menyebabkan kulit mengeras dan warnanya lebih gelap. Pengolahan limbah sebelum digunakan dapat mengatasi beberapa masalah meliputi kerusakan permukaan kulit, permukaan kasar dan warna gelap pada kulit (Zhuangdou Zhang, 2008).

Sebagai upaya pengelolaan limbah yang dihasilkan dapat dilakukan dengan cara penerapan produksi bersih yang salah satunya dilakukan melalui penerapan 3R (reuse, recycle and recovery). Dalam penelitian ini air yang digunakan untuk proses mulai dari perendaman sampai dengan pengasaman menggunakan air olahan wetland yang ada di Sitimulyo. Pemanfaatan kembali air olahan wetland merupakan salah satu upaya untuk mengurangi jumlah kebutuhan air bersih dalam proses penyamakan kulit dan mewujudkan kondisi yang ramah lingkungan. Tujuan penelitian ini untuk mempelajari pengaruh penggunaan air olahan wetland yang ada di Sitimulyo dalam pembuatan kulit pikel.

\section{BAHAN DAN METODE PENELITIAN}

\section{Bahan Penelitian}

Bahan penelitian terdiri atas : kulit domba awet garaman yang diperoleh dari PT. ASA, tepol, soda ash, kapur, $\mathrm{Na}_{2} \mathrm{~S}, \mathrm{NH}_{4} \mathrm{Cl}, \mathrm{ZA}$, bating agent, degreasing agent, garam, $\mathrm{HCOOH}, \mathrm{H}_{2} \mathrm{SO}_{4}$, anti jamur, kertas $\mathrm{pH}, \mathrm{BCG}$, air, air olahan wetland dari Sitimulyo Yogyakarta.

\section{Alat Penelitian}

Alat penelitian meliputi: drum eksperimen stainless steel ukuran $620 \times 300$ $\mathrm{mm}$, timbangan, gelas ukur, corong, pengaduk, boumemeter, mesin fleshing merk San Gok.

\section{Cara Penelitian}

Dalam penelitian ini faktor yang dipelajari adalah penggunaan air olahan wetland dari Sitimulyo yang diaplikasikan dalam proses penyamakan kulit mulai dari perendaman s/d pengasaman kulit domba. Jumlah air yang digunakan bervariasi dengan perbandingan air wetland: air bersih berturutturut 100:0, 75:25, 0:100. Kulit yang digunakan sebanyak 12 lembar kulit domba awet garaman yang dibagi dalam 4 kelompok. 
Kelompok I (100:0), II (75:25), III (50:50), dan IV (0:100). Masing-masing variasi dilakukan 3 kali ulangan (metode triplo).
Kulit domba awet garaman diproses sampai tahap pengasaman menggunakan formulasi seperti pada Tabel 2 .

Tabel 2. Formula Pembuatan Kulit Pikel dari kulit Domba

\begin{tabular}{|c|c|c|c|c|}
\hline Proses & Bahan Kimia & $\%$ & Waktu & Keterangan \\
\hline Pencucian & Air & & $\ldots$ & Bersih \\
\hline \multirow{3}{*}{ Perendaman } & Air* & 300 & $60^{\prime}$ & Cek pH $=9-10$ \\
\hline & Soda ash & 0,3 & & \\
\hline & Tepol & 0,5 & & \\
\hline \multirow[t]{6}{*}{ Pengapuran } & Air* & 100 & & \\
\hline & $\mathrm{Na}_{2} \mathrm{~S}$ & 2,5 & & \\
\hline & Kapur & 2 & 30 & Cek bulu rontok \\
\hline & Air* & 100 & & \\
\hline & Kapur & 4 & $\begin{array}{l}4 \times 20^{\prime} \text { putar } \\
30^{\prime} \text { stop }\end{array}$ & \\
\hline & Air* & 100 & & $\begin{array}{l}\text { ON, putar } 30 \text { ', cuci, } \\
\text { fleshing, timbang }\end{array}$ \\
\hline Deliming, & Air* & 100 & $90^{\prime}$ & Cek pH $=8,5$ \\
\hline Bating, & ZA & 1 & & Cuci \\
\hline \multirow[t]{3}{*}{ Degreasing } & $\mathrm{NH}_{4} \mathrm{Cl}$ & 1 & & \\
\hline & Palkobate & 0,75 & & \\
\hline & Degreasing agent & 0,7 & & \\
\hline \multirow[t]{5}{*}{ Pengasaman } & Air* & 80 & & \\
\hline & Garam & 10 & $10^{\prime}$ & Cek Be \\
\hline & $\mathrm{HCOOH}(1: 10)$ & 0,5 & $30^{\prime}$ & \\
\hline & $\mathrm{H}_{2} \mathrm{SO}_{4}(1: 20)$ & 1,1 & $3 \times 30$ & \\
\hline & Anti jamur $(1: 10)$ & 0,1 & $90^{\prime}$ & $\begin{array}{l}\mathrm{pH}=2,5 \\
\mathscr{\emptyset} \quad \text { kuning dengan } \\
\mathrm{BCG}\end{array}$ \\
\hline
\end{tabular}

Keterangan :

Air* = Air variasi proses

Air yang digunakan untuk pencucian tidak menggunakan air variasi proses

Tabel 3. Hasil pengujian air olahan wetland

\begin{tabular}{clcccc}
\hline \multirow{2}{*}{ No. } & \multirow{2}{*}{ Uraian } & Satuan & Hasil Pengujian & \multicolumn{2}{c}{ Persyaratan } \\
\cline { 5 - 6 } & & & & Min & Maks \\
\hline 1 & Kesadahan jumlah & $\mathrm{mg} / 1$ & 305 & - & 12 \\
2 & Kadar besi (Fe) & $\mathrm{mg} / 1$ & 0,0239 & - & 5 \\
3 & Kadar garam $(\mathrm{NaCl})$ & $\mathrm{mg} / 1$ & 2391,70 & - & 100 \\
4 & Kadar Permanganat & $\mathrm{mg} / 1$ & 86,90 & - & 5 \\
& $\left(\mathrm{KMnO}_{4}\right)$ & $\mathrm{mg} / 1$ & 0,26 & - & 50 \\
5 & Kekeruhan & - & 7,3 & 6 & 7,5 \\
6 & pH & & & & \\
\hline
\end{tabular}




\section{Pengujian}

Pengujian yang dilakukan:

1. Uji air wetland meliputi kesadahan jumlah, kadar besi, kadar garam, bilangan permanganat, kekeruhan dan $\mathrm{pH}$ sesuai SNI 06-0649-1989 tentang Air untuk Proses Penyamakan Kulit Samak Nabati

2. Uji kulit pikel meliputi uji kadar garam, kadar air, $\mathrm{pH}$ dan organoleptis sesuai SNI 06-3537-1994 tentang Mutu dan Cara Uji Kulit Pikel Domba/Kambing

\section{HASIL DAN PEMBAHASAN}

\section{Hasil uji air olahan wetland}

Hasil uji air olahan wetland terdapat pada Tabel 3 .

Dari hasil uji air olahan wetland didapatkan bahwa untuk kesadahan jumlah, kadar garam, dan bilangan permanganat tidak memenuhi syarat mutu air. Sedangkan untuk kadar besi, kekeruhan dan $\mathrm{pH}$ memenuhi syarat mutu air yang disyaratkan oleh SNI 060649-1989 mengenai air untuk proses penyamakan kulit samak nabati.

Kesadahan air olahan wetland sebesar 30,5 derajat jerman menunjukkan kalau air olahan wetland sitimulyo termasuk dalam golongan air sangat sadah. (Anonim, 1994).

Bilangan permanganat yang tinggi menunjukkan tingginya kandungan bahan organik dalam air sehingga mudah ditumbuhi oleh bakteri.

\section{Hasil Uji Kulit Pikel dari Kulit Domba Secara Kimiawi}

Hasil uji mutu kulit pikel domba secara kimiawi terdapat pada Tabel 4.

\section{a. Pengaruh jumlah air wetland terhadap kadar garam dalam kulit pikel}

Garam dibutuhkan dalam upaya pengawetan kulit. Berdasarkan analisa statistik hasil uji kadar garam dapat dilihat bahwa menunjukkan bahwa kadar garam pada penggunaan berbagai variasi perbandingan air wetland : air bersih dengan perbandingan $(100: 0 ; 75: 25 ; 50: 50)$ untuk semua variasi berbeda nyata terhadap kontrol $(0: 100)(\mathrm{p} \leq$ $0,05)$. Sedangkan perbandingan 75:25 tidak berbeda nyata dengan perbandingan 100:0.

Kulit pikel yang diproses menggunakan perbandingan air wetland : air bersih sebesar 100:0; 75:25; 50:50 memberikan nilai kadar garam yang berada di bawah kadar garam yang disyaratkan yaitu berturut turut 6,43 ; 6,$45 ; 5,37 \%$. Persyaratan kadar garam dalam SNI 06-3537-1994 tentang Mutu dan Cara Uji Kulit Pikel Domba/Kambing adalah minimal 8.

Tekanan osmotik $(\pi)$ adalah tekanan yang diberikan pada larutan yang dapat menghentikan perpindahan molekul-molekul pelarut ke dalam larutan melalui membran semi permeabel (proses osmosis). Kadar garam yang tinggi pada air olahan wetland menyebabkan tingginya tekanan osmosis dalam kulit sehingga menahan partikel garam yang akan masuk pori-pori kulit. Hal ini menyebabkan kadar garam terserap lebih kecil daripada yang diproses dengan menggunakan air besih. Menurut Purnomo (1985), pada kulit Pikel, garam dibutuhkan sebagai bahan buffer agar selama proses tidak mengalami pembengkakan saat penambahan asam dalam proses pickling. Reaksi osmosis dari garam mendesak air keluar dari kulit hingga tingkat kondisi yang tidak memungkinkan

Tabel 4. Hasil uji mutu kulit pikel domba secara kimiawi

\begin{tabular}{lccccc}
\hline Syarat-syarat kimiawi & $100: 0(\mathrm{I})$ & $75: 25(\mathrm{II})$ & $\begin{array}{c}50: 50 \\
(\mathrm{III})\end{array}$ & $\begin{array}{c}0: 100 \\
(\mathrm{k})\end{array}$ & Standard \\
\hline Kadar garam (\%) & $6,43 \mathrm{~b}$ & $6,45 \mathrm{~b}$ & $5,37 \mathrm{c}$ & $9 \mathrm{a}$ & Min 8 \\
Kadar air (\%) & $63,98 \mathrm{c}$ & $67,99 \mathrm{a}$ & $65,97 \mathrm{~b}$ & $59,32 \mathrm{~d}$ & Max 60 \\
$\mathrm{pH}$ & $3,03 \mathrm{~b}$ & $2,71 \mathrm{~d}$ & $2,95 \mathrm{c}$ & $3,29 \mathrm{a}$ & $1-2,5$ \\
\hline
\end{tabular}

Keterangan : angka-angka sekolom diikuti huruf sama tidak berbeda nyata menurut DMRT pada $\alpha=5 \%$ 
pertumbuhan bakteri. Dengan kadar garam yang lebih rendah menyebabkan kondisi lebih rentan terserang oleh bakteri. (Anonim,2012).

\section{b. Pengaruh jumlah air wetland terhadap kadar air dalam kulit}

Air merupakan perantara/medium untuk menyampaikan bahan-bahan ke dalam serat kulit. Berdasarkan analisa statistik hasil uji kadar air pada penggunaan berbagai variasi perbandingan air wetland:air bersih dengan perbandingan 100:0; 75:25; 50:50 menunjukkan bahwa hasil kadar air untuk semua variasi yang berbeda nyata terhadap kontrol $(0: 100)(p \leq 0,05)$.

Perbandingan air wetland: air bersih $=$ 0:100 (kontrol) memberikan nilai kadar air terbaik yang memenuhi standard SNI 063537-1994. Sedangkan untuk kulit Pikel yang diproses menggunakan perbandingan air wetland : air bersih sebesar 100:0; 75:25; 50:50 memberikan nilai kadar air yaitu 63,98; 67,$99 ; 65,97 \%$ yang berada di atas kadar air yang disyaratkan. Persyaratan kadar air dalam SNI 06-3537-1994 adalah maksimal $60 \%$.

Hal ini dikarenakan kadar garam yang tinggi dalam air olahan wetland. Sifat garam yang higroskopis menyebabkan air yang ada dalam kulit susah keluar dari kulit. Hal inilah yang menyebabkan kadar air dalam kulit lebih besar daripada kadar air kulit yang diproses dengan air bersih. (Hedisoebroto, 1990).

Hal ini berarti bahwa air wetland yang digunakan untuk proses belum bisa dimanfaatkan untuk proses penyamakan kulit.

\section{c. Pengaruh jumlah air wetland terhadap pH kulit pikel}

$\mathrm{pH}$ adalah derajat keasaman yang digunakan untuk menyatakan tingkat keasaman atau kebasaan yang dimiliki oleh suatu larutan.

Berdasarkan analisa statistik hasil uji $\mathrm{pH}$ pada penggunaan berbagai variasi perbandingan air wetland:air bersih (100:0; $75: 25$; 50:50) menunjukkan bahwa hasil $\mathrm{pH}$ berbeda nyata terhadap kontrol $(0: 100)(\mathrm{p} \leq$ $0,05)$.

Dari Tabel 4 dapat dilihat bahwa semua variasi tidak memenuhi $\mathrm{pH}$ yang disyaratkan pada SNI 06-3537-1994. Hasil uji pH dari variasi perbandingan air wetland:air bersih
$(100: 0 ; 75: 25 ; 50: 50)$ berturut-turut 3,03; 2,$71 ; 2,95$. Persyaratan $\mathrm{pH}$ dalam SNI 063537-1994 adalah antara 1-2,5. Hal ini diduga bahwa pada proses pikel masih kurang sempurna serta jumlah dan kualitas asam yang digunakan kurang sehingga belum mampu untuk menurunkan $\mathrm{pH}$. Proses pengasaman sangat dipengaruhi oleh jumlah garam, asam dan air yang digunakan.(Sarkar, 1991).

Lebih lanjut Sarkar (1991) menyatakan bahwa ketika terjadi proses pickling kulit akan mengabsorb asam dalam rendaman. $\mathrm{pH}$ dari rendaman Pikel $\mathrm{H}_{2} \mathrm{SO}_{4}-\mathrm{NaCl}$ akan mengalami kenaikan dari 1,7-2 menjadi 2,7-3,5. Kenaikan $\mathrm{pH}$ tersebut terjadi akibat absorpsi asam oleh kulit dan juga netralisasi kapur residu dalam kulit.

\section{Hasil Uji Organoleptis}

a. Pengaruh jumlah air wetland terhadap kenampakan nerf kulit Pikel

Dari pengamatan organoleptis nerf kulit pikel dari semua variasi menunjukkan adanya kesamaan flek yang terdapat pada kulit pikel. Sedangkan kulit pikel (kontrol) tidak terdapat flek. Hal ini dapat dilihat pada Gambar 1 dibawah ini.

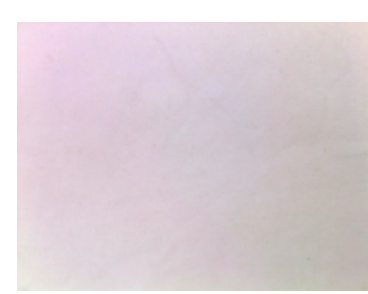

(a)

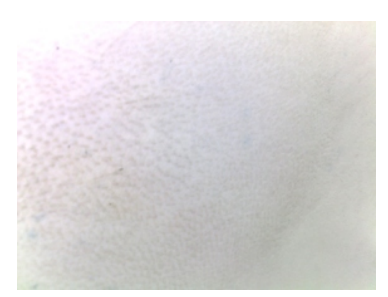

(c)

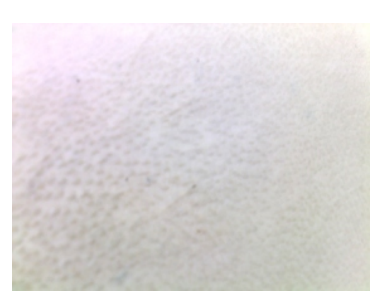

(b)

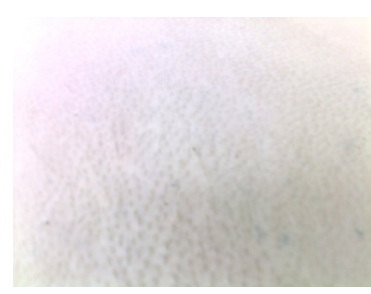

(d)
Gambar 1. Penampakan nerf kulit Pikel domba kontrol

(a) Nerf kulit Pikel kontrol, (b) Nerf kulit Pikel variabel I (c) Nerf kulit Pikel variabel II, (d) Nerf kulit Pikel variabel III

Hal ini sesuai dengan pendapat Jayusman (1990) yang menyatakan bahwa 
apabila air yang digunakan memiliki kesadahan yang tinggi akan menghambat proses misalnya dalam pengapuran akan terjadi flek flek $\mathrm{CaCO}_{3}$ dan pada proses Pikel terjadi flek $\mathrm{CaSO}_{4}$ yang dapat menurunkan mutu kulit. Hal ini ditunjukkan dengan kesadahan yang tinggi dari air olahan wetland yaitu sebesar 30,5 derajat jerman.

\section{b. Pengaruh jumlah air wetland terhadap bau kulit}

Hasil pengamatan organoleptis menunjukkan kulit yang diproses dengan menggunakan air wetland untuk semua variasi menghasilkan bau yang menyengat. Bau semakin menyengat dengan wetland yang semakin besar.

Hal ini dapat disebabkan karena bilangan permanganat yang tinggi. Bilangan permanganat adalah jumlah mg $\mathrm{KMnO}_{4}$ yang diperlukan untuk mengoksidasi zat organik yang terkandung didalam satu liter contoh air. Bilangan permanganat yang tinggi menunjukkan tingginya kandungan bahan organik dalam air wetland yang menyebabkan mudah berkembangnya bakteri. Kandungan bahan organik yang tinggi menyebabkan timbulnya bau yang menyengat. (Anonim, 2004).

\section{KESIMPULAN}

1. Air olahan wetland di Sitimulyo belum dapat memenuhi persyaratan air untuk proses penyamakan kulit

2. Penggunaan air wetland yang ada di Sitimulyo dalam proses pembuatan kulit Pikel dengan berbagai variabel air proses menyebabkan penurunan kualitas kulit Pikel yang dihasilkan

3. Kulit Pikel yang diproses menggunakan air wetland belum dapat memenuhi persyaratan kimiawi (kadar air, kadar garam dan $\mathrm{PH}$ ) dan secara organoleptis (nerf dan bau) yang tercantum dalam SNI 06-3537-1994 mengenai mutu dan cara uji kulit Pikel domba/ kambing.

\section{SARAN}

1. Pemanfaatan air olahan wetland di Sitimulyo sebaiknya dilakukan pengolahan yang intensif sebelum diterapkan pada proses penyamakan kulit

\section{DAFTAR PUSTAKA}

Anonim, 2007. Panduan Pengendalian Pencemaran Limbah Bahan Berbahaya Beracun pada Industri Penyamakan Kulit, Departemen Perindustrian, Jakarta

Anonim, 1994. "Pocket Book for the Leather Technologiest", $4^{\text {th }}$ edition, BASF, Jerman

Durai,G. And M. Rajasimman,2011. Biological Treatment of Tannery Waste Water A review. Journal of Enviromental Science and Technology 4 (1) : 1-17. 2011, Department of Chemical Engineering Annamalai University, India

Hedisoebroto. N, 1990. Dasar-dasar analis dan pemisahan kimia, ITB, Bandung

Iwan,K. dan Suryono, 2011. Wetland Technology for Domestic Wastewater Management

Jayusman, 1990. Pengetahuan Bahan, Balai Besar Kulit, Karet dan Plastik, Yogyakarta

Purnomo, E., 2005. Pengetahuan Dasar Teknologi Penyamakan Kulit, ATK, Yogyakarta

SNI 06-3537-1994, 1994. Mutu dan Cara Uji Kulit Pikel Domba/Kambing, Departemen Perindustrian

SNI 06-0649-1989, 1989. Air untuk Proses Penyamakan Kulit Samak Nabati, Departemen Perindustrian

SNI 06-6989.22-2004, 2004. Air dan Air Limbah - Bagian 22: Cara uji nilai permanganat secara titrimetri, Departemen Perindustrian

Sarkar, K.T. 1991. Theory and Practice of Leather Manufacture, The CLS Press, India

Zaenab, 2008. Industri Penyamakan Kulit dan Dampaknya terhadap Lingkungan

Zhiwen Ding, Yu Shuxian, Zhang Xiaolei, Gao Zhongbai, 2007. "Developing Countries Training Course on EcoLeather Manufacture Technology", China Leather and Footwear Industry Research Institute, China

Zhuangdou Zhang, 2008. Recycling of Waste Water from Raw Hide to Wet Blues in Leather Manufacture. Donyon Chemicals Co., Shanghai, China 